\title{
Pandemic 2020: Economic pressure and evaluation of a primary health care innovation programme for type 2 diabetes mellitus treatment
}

\author{
Fransiskus Samuel Renaldi ${ }^{1}$, Rani Sauriasari ${ }^{1}$, Woro Riyadina ${ }^{2}$ \\ ${ }^{1}$ Faculty of Pharmacy, Universitas Indonesia, Indonesia \\ ${ }^{2}$ Badan Penelitian dan Pengembangan Kesehatan, Indonesia
}

\author{
Keywords \\ COVID-19 \\ Compliance \\ Economic \\ Innovation \\ Pandemic \\ Type 2 Diabetes Mellitus \\ Correspondence \\ Rani Sauriasari \\ Faculty of Pharmacy \\ Prof. Dr. Mahar Mardjono St. \\ Campus of Universitas Indonesia \\ Depok \\ West Java 16424 \\ Indonesia \\ rani@farmasi.ui.ac.id
}

\begin{abstract}
Background: The COVID-19 pandemic has affected two vital sectors: the economy and health. Subsequently, people with type 2 diabetes mellitus (T2DM) face the dilemma of risking having a severe prognosis or non-compliance treatment. Aim: This study determines the relationship problems between the economic aspects and compliance behaviour in T2DM patients during the pandemic and how community health centres solve them. Methods: Data were collected from interviews with 20 T2DM patients and nine health workers in the Central Bogor region. The data were transcribed verbatim and analysed thematically. Results: Most patients tended to prioritise their economic condition. Besides, the community health centre has innovated an internet-based health service with particular policies to solve the problems. Conclusion: Economic pressure due to the COVID-19 pandemic has changed patients' mindsets. Community health centres respond with particular policies to sustain patient treatment adherence.
\end{abstract}

\section{Introduction}

Coronavirus disease 2019 (COVID-19) is a major problem affecting various countries, including Indonesia. In March 2020, the World Health Organization (WHO) declared the COVID-19 a pandemic (World Health Organization, 2020). Almost every sector in society has been affected, including the social, economic, political, cultural, defence, and security aspects. Governments have taken various measures to survive this pandemic situation (Kementrian Luar Negeri Republik Indonesia, 2020). This pandemic situation is also very closely related to patients with chronic diseases requiring regular medication. A specific type of patient prone to SARSCoV-2 (severe acute respiratory syndrome coronavirus 2) infection is type 2 diabetes mellitus patients (Guo et al., 2020). Type 2 diabetes mellitus (T2DM) is a risk factor that needs to be considered because it will accelerate the progression of COVID-19 and result in a worse prognosis (Hartmann-Boyce et al., 2020; Singh et al., 2020). Besides, T2DM caused the world's 1.5 million mortality rate in 2012 (Kementrian Kesehatan Republik Indonesia, 2016).

The pandemic has greatly disturbed Indonesia's economy, as reflected from the employee layoffs. Based on the Ministry of Manpower and BPJS Ketenagakerjaan data, 2.8 million workers were directly affected by COVID-19 (Badan Perencanaan Pengembangan Ketenagakerjaan, 2020). There were also 282 informal workers whose business was disrupted. Furthermore, according to the Indonesian Migrant Workers Protection 
Agency, 100,094 Indonesian Migrant Workers (PMI) from 83 countries returned to Indonesia in the last three months. The International Monetary Fund (IMF) projects that Indonesia's unemployment rate in 2020 could be at $7.5 \%$, an approximately 2.2\% increase from 2019 (Agustiana, 2020; Badan Pusat Statistik, 2020).

Several studies suggest that the economic aspect's impact is related to various aspects of other people's lives, including the health aspect (Allen \& Mirsaeidi, 2020; Pak et al., 2020). On the health side, the number of visits to health checks in different regions with the non-covid condition experienced a decreasing pattern caused by the social restriction policy (Pradana et al., 2020). In Yogyakarta, there was a decrease in chronic disease health check visits by $43 \%$ from April to May 2020 (Aildasari et al., 2020). Meanwhile, the number of visits to health checks in West Java were decreased by 50\% (Azizah et al., 2021).

Health checks are essential for monitoring patients with chronic diseases (Pradhan et al., 2020). Limited access to health services presents risks for patient adherence to treatment. In T2DM, patients are expected to take medication and undergo regular checkups to prevent complications and worsening life quality, on the one hand (Aloudah et al., 2018). On the other hand, it will be risky for a patient to visit a health facility for checkups during this pandemic (Apicella et al., 2020; Orioli et al., 2020). The potential risks that can occur during a pandemic for people with T2DM encourage the need for special monitoring of the therapy process, especially with the emergence of the Large-Scale Social Restriction policy, which has forced most patients to carry out their activities at home instead of outside (Koliaki et al., 2020).

An in-depth review is required to probe the root problems and provide possible solutions in dealing with the therapy of T2DM patients, which needs monitoring and adherence. This study aims to identify the socioeconomic situations that can affect patient treatment adherence and examine the functioning of innovative designs that health facilities need to implement to overcome a pandemic situation. The authors explored pre-implemented programs and policies by the Puskesmas (community health centre) in the Central Bogor area as a primary health facility to be used as a model for others. This study reviewed the socioeconomic phenomena during the 2020 pandemic that have affected treatment compliance of T2DM patients due to government and community health centre policies.

\section{Methods}

This study used a qualitative phenomenological research design. The qualitative design was chosen to explore the in-depth perceptions and thoughts of the research objects, i.e. T2DM, regarding the situation faced during the 2020 pandemic. This research was conducted in the Central Bogor area, especially in the operational areas of Puskesmas Sempur, Puskesmas Belong, and Puskesmas Merdeka. It was carried out during March-August 2020. This area was chosen because it has diverse individual characteristics and is expected to provide different pandemic perceptions. The data collection area for this research is in a densely populated city centre.

Before conducting this research, ethics permission was obtained from the Ethics Committee of the Faculty of Medicine, University of Indonesia. Data were collected via in-depth interviews, observations, and focus group discussions with participants. In this study, the participants were T2DM patients who used to undergo routine checkups at the local health centre, active health workers, and the head of the local Puskesmas, all of whom had signed informed consent forms as proof of involvement in the study. The health workers involved in this study were doctors, nurses, and pharmacists who directly deal with the patient's treatment process. Nine health workers from the three community health centres and 20 patients participated in this study. The interviews were carried out with the patients, while focus group discussions were held with the health workers and heads of Puskesmas for data confirmation.

The research data were validated by triangulating information between the interviews' results and direct observation of patients with the focus group discussions. The interviews were carried out using the probing technique and double-check method, in which each participant's answer was reconfirmed during the interview, then all answers were summarised and concluded at the end of the interview. The doublecheck method is carried out by using two interview methods: telephone and face-to-face. Also, data were validated by comparing the patients' data recorded at the local health facilities. The data were analysed based on interview transcripts, and then thematic analysis was performed to identify the pattern in each participant's statements.

\section{Results}

The authors made direct observations at the residence of some patients spread over the Central Bogor area. In-depth-interview with the patients were conducted simultaneously with the observations. A total of 20 patients were willing to participate in the study. Geographically, according to the observations, each Puskesmas area provides an overview of the different 
participant characteristics. The Puskesmas Belong area, near a marketplace, has patients whose occupations are traders or merchants, whose economic power relies heavily on sales. However, their dependency on work largely influences their treatment compliance. The Puskesmas Sempur and Puskesmas Merdeka areas have similar characteristics because they are near the main road, and the patients live in individual housing complexes on average. Most of them are company workers, while some open shops to support their economic activities.

\section{Participant economic conditions during the pandemic}

Generally, the patients live near each other in a large area. However, the roads are only one motorbikewide, except for places such as the Ministry of Agriculture neighbourhood, which is in the proximity of the Puskesmas Merdeka or Sempur neighbourhood areas. Some patients who live in the Babakan area, close to Bogor Agricultural University, rent out rooms at boarding houses to earn money. Unfortunately, the universities have implemented distanced learning, leading to a decrease in their income since the students are absent and reduced sales in some patient-owned snack businesses, laundry services, and nearby food stalls. Some patients stated that they were reluctant to buy medicines due to financial difficulties. This economic problem pressures them and hinders them from seeking treatment, especially if they are uninsured.

'... I do not want to go to the clinic because I have not had a BPJS (National Health Insurance) yet. If there is no BPJS, I am afraid. I am not ready because if you go to the doctor and do not bring IDR 500,000, I am afraid the doctor will examine everything, and it will increase the cost...'

Concerns about economic pressure ( $\mathrm{MW}$, complicated diabetes patient, adult)

'... In this situation, we have to think about ourselves, find food for ourselves, pay for the rent by ourselves; how do you sometimes feel confused when you pay rent because, in reality, you do not have any money....'

Concerns about economic pressure (S, complicated diabetes patient, adult)

Some patients who no longer have income chose to cut costs. As in the following statement, the patient tried to continue obtaining health care by downgrading his insurance membership class.

'... I do not make money already. I only get money from my children. So, in the end, I moved again to third grade (National Health Insurance), along with the three of us ....'
Health coverage condition (ES, complicated diabetes patient, elderly)

Some patients admitted that they are reluctant to undergo necessary specific medical procedures as costly, which encouraged them to choose cheaper alternative therapies to improve their existing conditions.

'... It was a day when I want to be given a referral to Cipto Hospital, but I am lazy because going to Cipto required so much money for the doctor. In the past of 2004, you needed a minimum IDR 500,000.00. It was expensive. I refused it, so I did not go to Cipto. When I went to my home, at Anyar Market, there was a potion maker, I was given eight kinds of potions, boiled them into three glasses, I drank a little, sir, it destroyed my gallstone, sir, so what do you say like that water is flickering, urine that after eating it. Alhamdulillah, until now, sir, thank God....'

Alternative medicine usage in patients ( $A A$, complicated diabetes patient, elderly)

The patients always wanted to live a healthy life, especially those in productive periods. Productiveperiod patients who had dependents were pushed to work naturally to meet the needs of family life. The condition forced them to take medicine because they would not meet their family's needs if they cannot work because of diabetes.

'... If I die, what do my children do? Who takes care of him, so what should I do? I try to take medicine because I am afraid there is something with me. My child motivates me. I want to be healthy because of my kids ....'

Concerns about adherence motivation (YA, complicated diabetes patient, adult)

Patients may have experienced confusion in choosing between money or being healthy because they believe that the two must go hand in hand. Without money, they believe that they cannot live and become costoriented in judging everything. Moreover, following inclusion in health programs, they would appreciate it if they were given money after joining the health program.

'... Patients sometimes do not take medication regularly because they do not get the knowledge or lack of funds to buy medicine. At the health centre or the Posbindu, the doctor explained that people with diabetes and high blood pressure regularly take their medication. After that, I got special money from the T2DM program because I diligently took medicine ....'

Patient motivation in treatment adherence $(\mathrm{NH}$, complicated diabetes patient, elderly) 
The concept of the patients' mindset, which highlights everything based on economic factors, was confirmed by the health volunteers, who were representatives of the community health centres. The volunteers found it difficult to persuade the patients because no amount of money can be offered for joining the program. Patients were unaware of the benefits of the program. As far as the patients knew, they were willing to participate in these activities because transport money is given as compensation. Had they understood the program better, they could have seen this as an opportunity for them to have their health checked free of charge.

'...yes, when it comes to money, surely everyone will come, but for Posbindu, whose programs are not given money, I usually have to go around, so I have to pick up one by one. However, if there is transport money, it is given immediately to come....'

Concerns about adherence motivation (public health volunteer, Belong)

Patients also shared various views on the government; some trusted it and felt that it had done its job in bringing health access closer to the public. That condition is vital concerning the patient's view of the government-owned health facilities available in their environment. Different mindsets, criticisms, and suggestions are received by the government, depending on their experience.

'... The government should pay attention to the pattern of public health. So far, if there are patients who come, they are just checked, but those who cannot come. How is her fate? They should be visited, checked at his house because it is safe. This kind of situation will be difficult, especially if people have to queue, instead of the risk of infectious diseases?...'

Concerns about the health care system in the pandemic era ( $S$, complicated diabetes patient, adult)

'... The government will not disappoint its people. They must think about health, prosperity, togetherness, community cohesiveness. So we do not have to blame the government. In any situation, especially the current situation, we should support the work of the government. The government cannot possibly torture its people. Maybe for others, there are cons, it does not matter. Of course, it is a form of input and support for the government...'

Opinion about the government in the health care system (UH, complicated diabetes patients, elderly)

'... At the moment, many government facilities have been repaired. BPJS, especially for treatment service, needs to be considered because many patients entering the hospital with BPJS must go home quickly before feeling healthy completely. However, in the future, hopefully, it will be better...'

Opinion about Universal Health Coverage in Indonesia (SM, complicated diabetes patient, adult)

\section{Government policies}

The patients also expected the government to fulfil their wishes.

'... I want to have a prosthetic leg. I used to get capital assistance from the government, but it is still lacking, and I cannot buy it until now. I still cannot buy it because the problem again is money.....'

Patient motivation in the treatment process $(R$, diabetes patient, adult)

'... I went to the Puskesmas and complained about the health workers' attitude. I said they were sick, but they did not have money. They do not want to be like that and only hope for government assistance. They want to be healthy, they want to have money like other people, but because it is God's destiny, I hope the Puskesmas does not differentiate between the services provided ....'

Concerns about the health care system $(N$, diabetes patient, adult)

The 2020 pandemic has significantly impacted how T2DM patients can obtain treatment. This condition is in line with the 'New Normal' policy by the government. Regarding T2DM, it has become more difficult for patients to monitor their blood sugar levels.

'... Right now, during the Corona pandemic, I feel scared, sir. I want to go to the Puskesmas, but I am afraid something will happen. So I did not go around, I just let it go....'

Concerns about a health condition in the pandemic era (SA, diabetes patient, elderly)

'... In the past, I often checked monthly, but now I do not. I usually wait for a doctor's referral to check the lab, but I cannot check it because of the current condition, even though I want to know my current health progress. However, because of the Corona, I was afraid of getting an infection...'

Concerns about a health condition in the pandemic era ( $M$, diabetes patient, adult)

Some Puskesmas adopted the policy of eliminating blood sugar checking services in the Puskesmas network (supporting Puskesmas). Moreover, the said services are only provided at the central Puskesmas, eventually forcing them to halt diabetes testing. The long distance between the patients' homes and the 
health centres has made it difficult for patients to attend checkups.

'... Because of Corona, I never checked my health. I want the pharmacy's control, but the pharmacy often closes quickly at 6:00 pm. I also do not take diabetes medicine now. Usually, at 6:00 am, I take my medication there and check everything, such as cholesterol, uric acid, and blood pressure. The last thing I remember, my sugar was high, 170. Before Corona, I used to control it every two weeks. However, until now, it has been a long time, about almost four months, I do not control it....'

Concerns about a health condition in the pandemic era (S, complicated diabetes patient, adult)

'... In the Corona era, I think it is too risky to take medication, especially if there is no strict health protocol. I am afraid that if medical treatment can spread the coronavirus, which can infect the community. It is not enough if you only wear a mask. You need to wear gloves to cut the distribution of the virus. I think, therefore, health facilities such as Puskesmas must be repaired....'

Concerns about the health care system in the pandemic era (ST, complicated diabetes patient, adult)

\section{Relationship with the health aspect}

The most visible problem was the access distance between the patient and the Puskesmas. The absence of blood sugar examination services at auxiliary Puskesmas during the pandemic led most patients to opt not to attend checkups there.

'... During this pandemic period, because the Puskesmas moved from Babakan to Sempur, I felt lazy. I have never been rechecked for health because it is very far from home ....'

Medical problems in patients during the pandemic $(\mathrm{N}$, complicated diabetes patient, elderly)

'... It is far away because usually in the house's Puskesmas, there is a laboratory section every day. Now I have to go to Merdeka Puskesmas. The Puskesmas near the house is closed now. It has been since the beginning of the pandemic ....'

Medical problems in patients during the pandemic (D, complicated diabetes patient, adult)

'... The Puskesmas, which is far away, is also uphill. So it is pretty tiring too. There is a Puskesmas here too, but they cannot check sugar ....'

Medical problems in patients during the pandemic (D, diabetes patient, adult)
Furthermore, the patients tried to change their diet. Some patients had opinions about what foods to avoid during this pandemic.

'... I do not eat chicken or any meat because I see it on television. I am worried that during the current Corona season, the food will catch the virus. So I have to be careful, sir, and the coronavirus is rapidly infecting diabetes patients. Alhamdulillah, I also take care of myself wearing a mask, sir ....'

Concerns about a health condition in the pandemic era (AA, complicated diabetes patient, elderly)

Aside from diet, the pandemic has affected patients' patterns. Correspondingly, many patients felt that the pandemic has made them unable to exercise again. The physical distancing policy has led to the closure of many public places for exercise to prevent crowds, including several parks where patients usually do aerobic exercise or other sports. In the end, many patients felt feeling unwell because they were not used to not exercising during the pandemic.

'... I can run, also sometimes participate in healthy gymnastics in the field before there is the Corona. All of these activities are my usual routine ....'

Concerns about a health condition in the pandemic era ( $S$, diabetes patient, elderly)

'... I exercise regularly. Since there was this Corona, I could not get out, so I could not exercise, so I do not feel well because I usually exercise, and now I do not....'

Concerns about a health condition in the pandemic era ( $S$, complicated diabetes patient, adult)

\section{Innovation for pandemic period adaptation}

Health facilities were also affected during the pandemic period. In preparation, every health facility will implement a unique strategy to anticipate pandemic conditions. Puskesmas is a primary health facility that is close to society. In one year, the Puskesmas has presented health programs oriented towards public health. Some Puskesmas have innovated by using an online system or establishing a policy of taking medication for one month; this was, of course, adjusted to the conditions at hand.

'... In the Non-Communicable Diseases program, we use an online system to register and have a quota because of this pandemic period. For example, Monday, we have five people, then we will prepare their medical records; all kinds of equipment will then be handed over to the doctor. The doctor will give a prescription and send it to the pharmacy. When patients arrive, they take medicine directly. This system is a solution during a pandemic to 
minimise the risk of transmission to patients, especially with diabetes mellitus cases....'

Health system innovation during a pandemic (Noncommunicable diseases programmer, Merdeka)

As long as it was supported by the Internet and knowledge of basic computing system operation, the online system ran smoothly and precisely. Social media groups, such as WhatsApp, were used. Besides distributing medicine properly, healthcare providers also provided health information through social media groups:

'... To keep the patient doing physical activity at home, doctors share videos containing the exercise method on the WhatsApp [WA] group. We do this so that they can still exercise themselves at home. So there are several groups in the WA group, elderly and adults. Several exercise videos have been shared, elderly exercise, Tobelo exercise, Zumba exercise, and creative exercise. Here are also various health information. The problem is that we cannot provide direct counselling, especially if we have to do in-depth counselling....'

Health system innovation during a pandemic (Noncommunicable diseases programmer, Merdeka)

Puskesmas need to innovate to ensure patients continue taking their medicines to control their blood sugar levels. Ease of access to medications must be secured, especially for patients who are BPJS participants. Puskesmas must guarantee that patients' rights are upheld, namely determining the latest diabetes mellitus status and obtaining medications.

'... Regarding treatment adherence problems, initially, we only gave the drug for two weeks. However, after an assessment was carried out during the pandemic period, it was found that many of our diabetes patients were elderly, which they were vulnerable to COVID infection. So we issued a policy of taking drugs to be once a month for their safety. However, we still inform patients if they feel that something is worsening; for example, they are not feeling well, they are welcome to take control at the Puskesmas....'

Health system innovation during a pandemic (Doctor, Belong)

Besides the online system innovation, policy adjustments were also made, like what Puskesmas Belong did, where it changed its policy for medication collection from 1-2 weeks to 1 month.

\section{Discussion}

The research transcript data indicated a strong relationship between economic factors and patient compliance behaviour. The COVID-19 pandemic situation has caused financial pressure that has impacted various sectors, including the health sector. Under economic pressure, patients have been forced to survive through their incomes. However, these incomes are prone to decline, pushing patients to be cost-effective, including in the health sector. Patients prefer to reduce drug purchases to reduce their spending. The data confirm that a person's economic condition would pressure the person (Cobden et al., 2010; Cutler et al., 2018; Lee et al., 2006). This pressure can influence a person's thought process and attitudes to adapt by making efforts to save themselves (Block et al., 2020; Yan et al., 2020).

\section{Economic pressures and changes in mindset}

This research shows that the economy and health are strongly correlated (Aptel \& Toren, 2020). This relationship ultimately impacts patient therapy. Economic limitations can force patients to choose alternative treatments instead of the anticipated medical actions. In financial stress situations, the patient struggles to stay afloat (Al-Hasan et al., 2020). Healthcare costs make a large portion of the patient's expenditure, especially for patients with special conditions, such as diabetes with very high sugar levels, diabetic foot infection, and kidney deterioration due to diabetes (Andersson et al., 2020; Visaria et al., 2020). Patients do everything they can to survive with the existing limitations (Ding et al., 2020; Hooft et al., 2020). They have to support their families while living in fear of being unable to fulfil their basic daily needs due to the economic downturn. This fear ultimately affects the patient's treatment compliance behaviour (Hall, 2020; Markovski, 2020). The close relationship between the economy and health positively impacts the patient's life (Aptel \& Toren, 2020). The patients believe that they cannot live without money. The thought processes presented in the present study are oriented towards money as an indicator of their economy. Economic pressure can change the patient's mindset (Nguyen et al., 2020; Sajjad \& Shahbaz, 2020).

Various things cannot be separated from the government's role in striving for public access to health services (Fafard \& SJ, 2020; Hunger et al., 2020). Patients and the government will have different opinions, depending on their experience (Frizelle, 2020). In the present study, the patients also expect the government to fulfil their wishes. The government serves the public and is obliged to meet the community's various needs (Greer et al., 2020; 
Ukhalkar, 2019). Patients who feel that their needs have been met will have a positive outlook (Putri \& Wirawati, 2020). However, if they experience less pleasant services, they will criticise them until their expectations are met (Salokhiddinovich \& Farrukh, 2020). The government can indeed be described as a place for patients to receive assistance for their survival, especially those who are not financially independent (Warner et al., 2020).

The 2020 pandemic has significantly impacted how diabetes mellitus patients can obtain treatment. Many patient behaviours will change alongside the adaptation process in overcoming this pandemic (Acuña-Zegarra et al., 2020; Bavel et al., 2020). In the end, patients will also have to adapt to continue their normal activities (Weill et al., 2020). This condition is in line with the government's New Normal policy. Changes in health facility policies due to the pandemic will directly impact the patients (Rosenbaum, 2020; Shayak et al., 2020). Patients tend to follow the existing policies hoping that they can solve their problem. Many patients want to comply with treatment, but this conflicts with daily activities, work, and economic pressures.

\section{Impact on health aspect dan innovations}

One of the main problems is the patients' lack of access to the Puskesmas. During this pandemic, difficult access impedes patient communication with medical workers. An innovation regarding this issue needs to be made to allow patients to obtain adequate information and health services (Crespo-Gonzalez et al., 2020). Health facilities must anticipate this condition by providing health services to patients and thinking about new strategies to sustain treatment adherence. In the case of T2DM, the patient's sugar level must be continuously monitored. Health policies will be taken in line with occurring developments (Raboisson \& Lhermie, 2020).
Every health facility will carry out unique strategies to anticipate pandemic conditions. During this time, the concern is handling things quickly and accurately, especially for COVID-19-infected patients in the area (Legido-Quigley et al., 2020). Of course, the referral system and the like are prepared following Central Government policies.

T2DM is a specific comorbid disease that is highly risky during this pandemic. The risk of mortality will increase more in patients with diabetes mellitus (Zhou et al., 2020); thus, it has to be controlled (Riddle et al., 2020). Patients must do regular checkups to monitor the disease and take medicines. As a government-owned health facility, Puskesmas has a system that must align with existing policies and develop innovations to continue on its programs (Buffart et al., 2020). Puskesmas must also carry out their functions optimally under government regulations and policies.

Puskesmas is a primary health facility that is close to society. In one year, the Puskesmas has health programs that are oriented towards public health. The programs run by Puskesmas must have the critical aim of improving health status, even during this pandemic. All forms of technical policies made must be able to support public health. In handling non-communicable diseases, in this case, T2DM, Puskesmas still has to ensure the patient's access to health services. The present study shows that an online system provides an easy coordination pattern with minimal risk. This system can be the safest choice because of its fastpaced nature, minimal physical contact, and easy operation (Allam et al., 2020; Chen et al., 2020). As long as it is supported by the Internet and knowledge of basic computing system operation, the online system will run smoothly and precisely (Smith et al., 2020). Figure 1 shows how the community health centre built the innovation system.

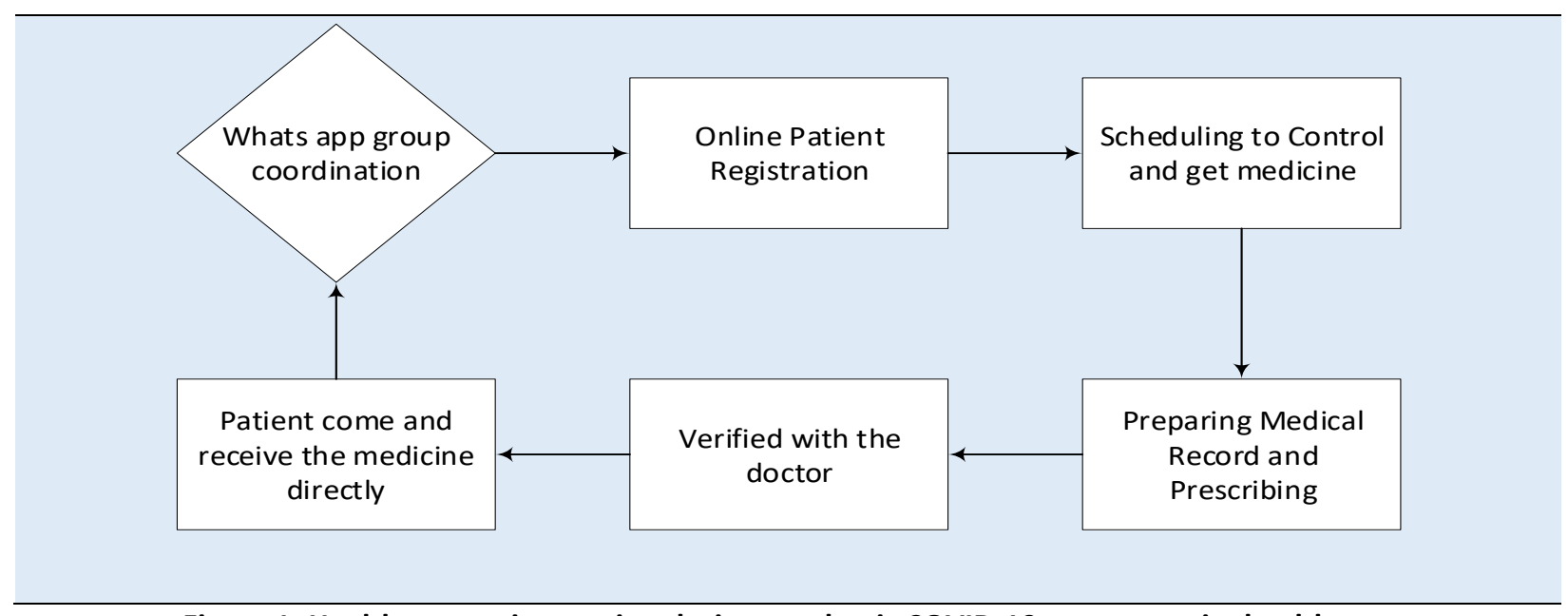

Figure 1: Health system innovation during pandemic COVID-19 at community health centres 
The innovation system was built to ensure that patients can still carry out routine diabetes mellitus checks to ease monitoring. It can be said that the system's description is in line with the standard protocol for a routine examination at a health centre; the difference is that it is coordinated through the social media group WhatsApp. In pandemic conditions, contact with areas of infection, such as health facilities, must be minimised, including contact when patients register manually. The system is built to accelerate the administration process for patients to receive their medicines immediately without physical contact with the prescribing doctor. However, this creates a gap in the monitoring process; hence, the patient's diabetes condition cannot be observed directly since the consultation is performed online.

Telemedicine, a combination of technology and medical action that can be executed through social media applications such as WhatsApp, is a mechanism for which implementation is necessary during the pandemic to prevent the viral infection spread that is risky for T2DM patients (Budd et al., 2020). WhatsApp is widely used because of its cheap and user-friendly features for many social classes. However, its capacity is limited to fewer than 300 members in a group. Another possible alternative is Telegram, where one group can accommodate up to 5000 members. Given sufficient numbers of members, the Puskesmas can consider Telegram as an alternative (Kamarudin et al., 2020; Masoni \& Guelfi, 2020).

Disseminating information via online coordination between health workers and patients will minimise the spread of false news (Budd et al., 2020). The online system's weakness is that not all patients can fully utilise this facility, especially elderly patients who are not tech-savvy (Gerke et al., 2020). However, this information can be relayed through the patient's family members, as they would help maintain its veracity. After all, the environment also plays a role in the patient's life (Fafard \& SJ, 2020). Puskesmas needs to accommodate the accuracy of information so that it can be conveyed to the public. At the very least, this coordination should extend to the patient's family or closest relatives. Health cadres and community leaders can be persuaded to disseminate this information (Putri \& Wirawati, 2020).

Efforts to achieve patient compliance are also the responsibility of the Puskesmas. Puskesmas need to innovate on making patients continue taking their medicines to control their blood sugar levels. As a public health facility, the Puskesmas must guarantee that the patient's rights are upheld, namely determining the latest diabetes mellitus status and obtaining medications. Another possible form of innovation is policy adjustments, as Puskesmas Belong did, which changed its policy of medication collection from 1-2 weeks to monthly. The Puskesmas stated that this was to prevent vulnerable patients from being exposed to COVID-19, as T2DM patients are high-risk patients. This change does have a drawback, namely, difficulties in controlling the patients' blood sugar levels. However, this problem can be anticipated by providing access for patients to be served whenever they need it. Decision-making and policy implementation is certainly not without risks (Greer et al., 2020; Salokhiddinovich \& Farrukh, 2020). Therefore, it is more appropriate to make decisions and policies based on minimal risk for patients while ensuring flexibility to change over time.

\section{Study limitations}

This innovation can be a form of vertical policy implementation to maintain health services' availability to patients. With this system, it is hoped that patients will continue to comply with treatment, even in a pandemic situation. This cutting-edge model is implementable, as many patients also have the technology to apply it. Nevertheless, this research is limited to the innovation model developed by the Puskesmas in the Central Bogor area; further analyses of other parts of the region or types of health facilities are required. The impact of the innovation on patient adherence problems should be examined, so further research is needed to evaluate the model's application. This implementation must be seen in various circles, where some patients are known to have neither the necessary tools nor the aptitude of technology for online treatments. The drug-taking policy also requires evaluation to assess the possible challenges of controlling patient adherence due to minimal contact with health workers.

\section{Conclusion}

This study shows that economic pressure can change the patient's mindset, significantly affecting medication adherence in type 2 diabetes mellitus treatment. The deteriorating financial condition discourages patients from prioritising routine health checks at health facilities because of reluctance to pay medical expenses. Concerning the problem of treatment compliance, three community health centres in Central Bogor Region implemented an innovation in the form of an Internet-based health service system with WhatsApp groups and a medication collection policy to minimise the risk of contact with areas of infection. This study still has limitations on the variety of innovations observed and the extent of their impact. Further 
studies are needed to see other pilot projects during a pandemic and evaluate those carried out so far.

\section{Acknowledgements}

The authors express gratitude towards the heads of the Puskesmas Sempur, Belong, Merdeka, and health workers who participated in the focus group discussion activities. The authors also thank the patients who were willing to participate in the study, providing useful data to advance science and public health. The authors also wish to acknowledge the Researcher for Human Resources Development at the Ministry of Health of the Republic of Indonesia for funding this research so that this study could progress smoothly. . Finally, the authors are also grateful to the Ministry of Research and Technology/National Agency for Research and Innovation, the Republic of Indonesia, for giving us financial support through PDUPT Grant No. NKB93/UN2.RST/HKP.05.00/2020 and Addendum No. NKB2692/UN2.RST/HKP.05.00/2020.

\section{References}

Acuña-Zegarra, M. A., Santana-Cibrian, M., \& VelascoHernandez, J. X. (2020). Modeling behavioral change and COVID-19 containment in Mexico: A trade-off between lockdown and compliance. Mathematical Biosciences, 325, 108370. https://doi.org/10.1016/j.mbs.2020.108370

Agustiana, L. E. (2020). Pengaruh Wabah COVID-19 Terhadap Tingkat Pengangguran Terbuka Pada Sektor Terdampak Di Indonesia. Jurnal IImu Manajemen Terapan, 1(6), 546-556. https://doi.org/10.31933/jimt.v1i6.209

Aildasari, E. N., Karomah, I. N., Hayati, N., Fajriyah, K. N., \& Habib, F. H. (2020). Pemeriksaan Kesehatan Lansia Dan Balita Dalam Upaya Pemantauan Kesehatan Melalui Kegiatan Posyandu Di Masa Pandemic COVID-19 Di Desa Kalimulyo, Jakenan, Pati, Jawa Tengah. 5

Al-Hasan, A., Yim, D., \& Khuntia, J. (2020). Citizens' Adherence to COVID-19 Mitigation Recommendations by the Government: A 3-Country Comparative Evaluation Using Web-Based Cross-Sectional Survey Data. Journal of Medical Internet Research, 22(8), e20634. https://doi.org/10.2196/20634

Allam, Z., Dey, G., \& Jones, D. S. (2020). Artificial Intelligence (Al) Provided Early Detection of the Coronavirus (COVID-19) in China and Will Influence Future Urban Health Policy Internationally. Al, 1(2), 156-165. https://doi.org/10.3390/ai1020009

Allen, M. B., \& Mirsaeidi, M. (2020). Health and Economy in COVID-19 Era: A Plan for Reconstituting Long-Term Economic Security. Frontiers in Public Health, 8. https://doi.org/10.3389/fpubh.2020.00235
Aloudah, N. M., Scott, N. W., Aljadhey, H. S., Araujo-Soares, V., Alrubeaan, K. A., \& Watson, M. C. (2018). Medication adherence among patients with Type 2 diabetes: A mixed methods study. PLOS ONE, 13(12). https://doi.org/10.1371/journal.pone.0207583

Andersson, E., Persson, S., Hallén, N., Ericsson, Å., Thielke, D., Lindgren, P., Carlsson, K. S., \& Jendle, J. H. (2020). 1165-P: Costs of Diabetes Complications: Hospital-Based Care and Production Loss for 392,200 People with Type 2 Diabetes and Matched Controls. Diabetes, 69(Supplement 1). https://doi.org/10.2337/db20-1165-P

Apicella, M., Campopiano, M. C., Mantuano, M., Mazoni, L., Coppelli, A., \& Prato, S. D. (2020). COVID-19 in people with diabetes: Understanding the reasons for worse outcomes. The Lancet Diabetes \& Endocrinology, 8(9), 782-792. https://doi.org/10.1016/S2213-8587(20)30238-2

Aptel, F., \& Toren, A. (2020). Societal and Economic Impact of Poor Glaucoma Medication Adherence. Ophthalmology, 127(5), 599-600.

https://doi.org/10.1016/j.ophtha.2020.02.015

Azizah, A. N., Raodhah, S., Surahmawati, S., \& Alam, S. (2021). Utilisation of The Chronic Disease Management Program During The COVID-19 Pandemic. Diversity: Disease Preventive of Research Integrity, 1(1), 21-29. https://doi.org/10.24252/diversity.v1i1.18724

Badan Perencanaan Pengembangan Ketenagakerjaan. (2020, July 12). Profil Ketenagakerjaan Umum Agustus 2020 [Goverment Website]. Satu Data. https://satudata.kemnaker.go.id/

Badan Pusat Statistik. (2020, November 5). Agustus: Tingkat Pengangguran Terbuka (TPT) sebesar 7,07 persen [Goverment Website]. https://www.bps.go.id/pressrelease/2020/11/05/1673/agus tus-2020--tingkat-pengangguran-terbuka--tpt--sebesar-707-persen.html

Bavel, J. J. V., Baicker, K., Boggio, P. S., Capraro, V., Cichocka, A., Cikara, M., Crockett, M. J., Crum, A. J., Douglas, K. M., Druckman, J. N., Drury, J., Dube, O., Ellemers, N., Finkel, E. J., Fowler, J. H., Gelfand, M., Han, S., Haslam, S. A., Jetten, J., ... Willer, R. (2020). Using social and behavioural science to support COVID-19 pandemic response. Nature Human Behaviour, 4(5), 460-471. https://doi.org/10.1038/s41562020-0884-z

Block, R., Berg, A., Lennon, R. P., Miller, E. L., \& Nunez-Smith, M. (2020). African American Adherence to COVID-19 Public Health Recommendations. HLRP: Health Literacy Research and Practice, 4(3), e166-e170. https://doi.org/10.3928/24748307-20200707-01

Budd, J., Miller, B. S., Manning, E. M., Lampos, V., Zhuang, M., Edelstein, M., Rees, G., Emery, V. C., Stevens, M. M., Keegan, N., Short, M. J., Pillay, D., Manley, E., Cox, I. J., Heymann, D., Johnson, A. M., \& McKendry, R. A. (2020). Digital technologies in the public-health response to COVID-19. Nature Medicine, 26(8), 1183-1192. https://doi.org/10.1038/s41591-020-1011-4

Buffart, M., Croidieu, G., Kim, P. H., \& Bowman, R. (2020). Even winners need to learn: How government entrepreneurship programs can support innovative ventures. 
$\begin{array}{llll}\text { Research Policy, } & \text { 49(10), } & 104052 .\end{array}$ https://doi.org/10.1016/j.respol.2020.104052

Chen, T., Peng, L., Yin, X., Rong, J., Yang, J., \& Cong, G. (2020). Analysis of User Satisfaction with Online Education Platforms in China during the COVID-19 Pandemic. Healthcare, 8(3), 200. https://doi.org/10.3390/healthcare8030200

Cobden, D. S., Niessen, L. W., Rutten, F. F., \& Redekop, W. K. (2010). Modeling the economic impact of medication adherence in type 2 diabetes: A theoretical approach. Patient Preference and Adherence, 4, 283-290

Crespo-Gonzalez, C., Benrimoj, S. I., Scerri, M., \& GarciaCardenas, V. (2020). Sustainability of innovations in healthcare: A systematic review and conceptual framework for professional pharmacy services. Research in Social and Administrative Pharmacy, 16(10), 1331-1343. https://doi.org/10.1016/j.sapharm.2020.01.015

Cutler, R. L., Fernandez-Llimos, F., Frommer, M., Benrimoj, C., \& Garcia-Cardenas, V. (2018). Economic impact of medication nonadherence by disease groups: A systematic review. BMJ Open, 8(1), e016982. https://doi.org/10.1136/bmjopen-2017-016982

Ding, A., Patel, J. P., \& Auyeung, V. (2020). Understanding the Traditional Chinese Medicine (TCM) consultation: Why do patients adhere to treatment? Complementary Therapies in Clinical Practice, 39, 101139. https://doi.org/10.1016/j.ctcp.2020.101139

Fafard, P., \& SJ, H. (2020, April 19). Rethinking knowledge translation for public health policy - Research Impact Canada. http://researchimpact.ca/rethinking-knowledgetranslation-for-public-health-policy/

Frizelle, F. (2020, July 31). Has the present government delivered the health policy that it promised before it was elected? https://www.nzma.org.nz/journal-articles/has-thepresent-government-delivered-the-health-policy-that-itpromised-before-it-was-elected

Gerke, S., Shachar, C., Chai, P. R., \& Cohen, I. G. (2020). Regulatory, safety, and privacy concerns of home monitoring technologies during COVID-19. Nature Medicine, 26(8), 1176-1182. https://doi.org/10.1038/s41591-020-0994-1

Greer, S. L., King, E. J., Fonseca, E. M. da, \& Peralta-Santos, A. (2020). The comparative politics of COVID-19: The need to understand government responses. Global Public Health, 15(9),

https://doi.org/10.1080/17441692.2020.1783340

1413-1416.

Guo, W., Li, M., Dong, Y., Zhou, H., Zhang, Z., Tian, C., Qin, R., Wang, H., Shen, Y., Du, K., Zhao, L., Fan, H., Luo, S., \& Hu, D. (2020). Diabetes is a risk factor for the progression and prognosis of COVID-19. Diabetes/Metabolism Research and Reviews, e3319. https://doi.org/10.1002/dmrr.3319

Hall, G. L. (2020). Connecting with Stories: Improving Patient Adherence and Compliance. In G. L. Hall (Ed.), PatientCentered Clinical Care for African Americans: A Concise, Evidence-Based Guide to Important Differences and Better Outcomes (pp. 191-201). Springer International Publishing. https://doi.org/10.1007/978-3-030-26418-5_14

Hartmann-Boyce, J., Morris, E., Goyder, C., Kinton, J., Perring, J., Nunan, D., Mahtani, K., Buse, J. B., Prato, S. D., Ji, L., Roussel, R., \& Khunti, K. (2020). Diabetes and COVID-19:
Risks, Management, and Learnings From Other National Disasters. Diabetes Care. https://doi.org/10.2337/dc20-1192

Hooft, A., Nabukalu, D., Mwanga-Amumpaire, J., Gardiner, M. A., \& Sundararajan, R. (2020). Factors Motivating Traditional Healer versus Biomedical Facility Use for Treatment of Pediatric Febrile Illness: Results from a Qualitative Study in Southwestern Uganda. The American Journal of Tropical Medicine and Hygiene, 103(1), 501-507. https://doi.org/10.4269/ajtmh.19-0897

Hunger, J. M., Smith, J. P., \& Tomiyama, A. J. (2020). An Evidence-Based Rationale for Adopting Weight-Inclusive Health Policy. Social Issues and Policy Review, 14(1), 73-107. https://doi.org/10.1111/sipr.12062

Kamarudin, N. K., Bismi, N. S., Zukri, N. H. A., Fuzi, M. F. M., \& Ramle, R. (2020). Network Security Performance Analysis of Mobile Voice Over Ip Application (mVolP): Kakao Talk, WhatsApp, Telegram and Facebook Messenger. Journal of Computing Research and Innovation, 5(2), 21-27

Kementrian Kesehatan Republik Indonesia. (2016). Foto Fakta dan Angka Diabetes. Direktorat P2PTM. http://p2ptm.kemkes.go.id/foto-p2ptm/fakta-dan-angkadiabetes

Kementrian Luar Negeri Republik Indonesia. (2020). KEBIJAKAN PEMERINTAH REPUBLIK INDONESIA TERKAIT WABAH COVID-19. Kedutaan Besar Republik Indonesia Di Belgia.

https://kemlu.go.id/brussels/id/news/6349/kebijakanpemerintah-republik-indonesia-terkait-wabah-covid-19

Koliaki, C., Tentolouris, A., Eleftheriadou, I., Melidonis, A., Dimitriadis, G., \& Tentolouris, N. (2020). Clinical Management of Diabetes Mellitus in the Era of COVID-19: Practical Issues, Peculiarities and Concerns. Journal of Clinical Medicine, 9(7), 2288. https://doi.org/10.3390/jcm9072288

Lee, W. C., Balu, S., Cobden, D., Joshi, A. V., \& Pashos, C. L. (2006). Medication adherence and the associated healtheconomic impact among patients with type 2 diabetes mellitus converting to insulin pen therapy: An analysis of third-party managed care claims data. Clinical Therapeutics, 28(10), https://doi.org/10.1016/j.clinthera.2006.10.004

1712-1725.

Legido-Quigley, H., Asgari, N., Teo, Y. Y., Leung, G. M., Oshitani, H., Fukuda, K., Cook, A. R., Hsu, L. Y., Shibuya, K., \& Heymann, D. (2020). Are high-performing health systems resilient against the COVID-19 epidemic? The Lancet, 395(10227), 848-850. https://doi.org/10.1016/S01406736(20)30551-1

Markovski, T. (2020). Physical Therapists Perceptions Of Patient Adherence And Strategies For Facilitating Motivation. Theses and Dissertations. https://doi.org/10.30707/ETD2020.Markovski.T

Masoni, M., \& Guelfi, M. R. (2020). WhatsApp and other messaging apps in medicine: Opportunities and risks. Internal and Emergency Medicine, 15(2), 171-173. https://doi.org/10.1007/s11739-020-02292-5

Nguyen, H.-T.-M., Do, H., Kay, A., \& Kompas, T. (2020). Rice policy in a transitional economy: Balancing the social and political objectives. Food Security, 12(3), 549-566. https://doi.org/10.1007/s12571-019-01005-x 
Orioli, L., Hermans, M. P., Thissen, J.-P., Maiter, D., Vandeleene, B., \& Yombi, J.-C. (2020). COVID-19 in diabetic patients: Related risks and specifics of management. https://www.unboundmedicine.com/medline/citation/3241 3342/COVID_19_in_diabetic_patients:_Related_risks_and_s pecifics_of_management_

Pak, A., Adegboye, O. A., Adekunle, A. I., Rahman, K. M., McBryde, E. S., \& Eisen, D. P. (2020). Economic Consequences of the COVID-19 Outbreak: The Need for Epidemic Preparedness. Frontiers in Public Health, 8. https://doi.org/10.3389/fpubh.2020.00241

Pradana, A. A., Casman, C., \& Nur'aini, N. (2020). Pengaruh Kebijakan Social Distancing pada Wabah COVID-19 terhadap Kelompok Rentan di Indonesia. Jurnal Kebijakan Kesehatan Indonesia : JKKI, 9(2), 61-67. https://doi.org/10.22146/jkki.55575

Pradhan, A., Bogue, E., Schreiber, B., Dini, H. S., Hurkchand, H., Briggs, J., \& Ballard, M. (2020). Availability of Essential Commodities and Related Bottlenecks for Community Health System: Systematic Literature Review [Preprint]. In Review. https://doi.org/10.21203/rs.3.rs-24276/v3

Putri, I. G. A. M. A. D., \& Wirawati, N. G. P. (2020). Implementation of good government governance, intellectual intelligence, emotional, and spiritual intelligence in managerial performance of village government management. International Research Journal of Management, IT and Social Sciences, 7(1), 169-176. https://doi.org/10.21744/irjmis.v7n1.831

Raboisson, D., \& Lhermie, G. (2020). Living With COVID-19: A Systemic and Multi-Criteria Approach to Enact EvidenceBased Health Policy. Frontiers in Public Health, 8. https://doi.org/10.3389/fpubh.2020.00294

Riddle, M. C., Buse, J. B., Franks, P. W., Knowler, W. C., Ratner, R. E., Selvin, E., Wexler, D. J., \& Kahn, S. E. (2020). COVID-19 in People With Diabetes: Urgently Needed Lessons From Early Reports. Diabetes Care. https://doi.org/10.2337/dci20-0024

Rosenbaum, L. (2020). The Untold Toll-The Pandemic's Effects on Patients without COVID-19. New England Journal of Medicine, 382(24), 2368-2371. https://doi.org/10.1056/NEJMms2009984

Sajjad, A., \& Shahbaz, W. (2020). Mindfulness and Social Sustainability: An Integrative Review. Social Indicators Research, 150(1), 73-94. https://doi.org/10.1007/s11205020-02297-9

Salokhiddinovich, T. A., \& Farrukh, A. (2020). The Impact of Changes in Public Administration on the Development of Neoconservative Ideas in the United States. International Journal of Advanced Science and Technology, 29(3), 81048114

Shayak, B., Sharma, M. M., Rand, R. H., Singh, A. K., \& Misra, A. (2020). Transmission Dynamics of COVID-19 and Impact on Public Health Policy. MedRxiv, 2020.03.29.20047035. https://doi.org/10.1101/2020.03.29.20047035

Singh, A. K., Gupta, R., Ghosh, A., \& Misra, A. (2020). Diabetes in COVID-19: Prevalence, pathophysiology, prognosis and practical considerations. Diabetes \& Metabolic Syndrome, 14(4), 303-310. https://doi.org/10.1016/j.dsx.2020.04.004

Smith, A. C., Thomas, E., Snoswell, C. L., Haydon, H., Mehrotra, A., Clemensen, J., \& Caffery, L. J. (2020). Telehealth for global emergencies: Implications for coronavirus disease 2019 (COVID-19). Journal of Telemedicine and Telecare, 26(5), 309-313. https://doi.org/10.1177/1357633X20916567

Ukhalkar, P. (2019). The Transformative Potential Benefits of Big Data in Government and Public Sector Domains. 1, 5.

Visaria, J., Iyer, N. N., Raval, A. D., Kong, S. X., Hobbs, T., Bouchard, J., Kern, D. M., \& Willey, V. J. (2020). Healthcare Costs of Diabetes and Microvascular and Macrovascular Disease in Individuals with Incident Type 2 Diabetes Mellitus: A Ten-Year Longitudinal Study. ClinicoEconomics and Outcomes Research: CEOR, 12, 423-434. https://doi.org/10.2147/CEOR.S247498

Warner, M. E., Aldag, A. M., \& Kim, Y. (2020). Privatisation and intermunicipal cooperation in US local government services: Balancing fiscal stress, need and political interests. Public Management Review, 0(0), 1-18. https://doi.org/10.1080/14719037.2020.1751255

Weill, J. A., Stigler, M., Deschenes, O., \& Springborn, M. R. (2020). Social distancing responses to COVID-19 emergency declarations strongly differentiated by income. Proceedings of the National Academy of Sciences, 117(33), 19658-19660. https://doi.org/10.1073/pnas.2009412117

World Health Organization. (2020). Timeline: WHO's COVID19 response. WHO. https://www.who.int/emergencies/diseases/novelcoronavirus-2019/interactive-timeline

Yan, L. D., Pierre-Louis, D., Isaac, B. D., Jean-Baptiste, W., Vertilus, S., Fenelon, D., Hirschhorn, L. R., Hibberd, P. L., Benjamin, E. J., Bukhman, G., \& Kwan, G. F. (2020). Does distance from a clinic and poverty impact visit adherence for non-communicable diseases? A retrospective cohort study using electronic medical records in rural Haiti. BMC Public Health, 20(1), 1545. https://doi.org/10.1186/s12889-02009652-y

Zhou, Y., Chi, J., Lv, W., \& Wang, Y. (2020). Obesity and diabetes as high-risk factors for severe coronavirus disease 2019 (COVID-19). Diabetes/Metabolism Research and $\begin{array}{lll}\text { Reviews, } & \mathrm{n} / \mathrm{a}(\mathrm{n} / \mathrm{a}), & \mathrm{e}\end{array}$ https://doi.org/10.1002/dmrr.3377 